\title{
A CONTRASTIVE ANALYSIS OF SIMPLE SENTENCES IN ENGLISH AND JAVANESE LANGUAGE
}

\author{
Fitriyani, D.P. Ramendra, I.W. Swandana \\ Jurusan Pendidikan Bahasa Inggris, Universitas Pendidikan Ganesha, Singaraja, \\ e-mail: fitriyani.eed14\}@yahoo.com, dewaramendra\}@yahoo.com, wayan swandana@yahoo.com
}

\begin{abstract}
ABSTRAK
Penelitian ini meneliti tentang kalimat sederhana bahasa inggris dan bahasa jawa yang bertujuan untuk menemukan perbedaan dan persamaan kalimat sederhana dalam bahasa inggris dan bahasa jawa. Penelitian ini merupakan deskritif kualitatif menggunakan analisis kontrastif sebagai metode analisis. Data diambil dari buku bahasa inggris dan majalah bahasa jawa. Hasil penelitian menunjukan adanya perbedaan dan persamaan antara kalimat sederhana dalam bahasa inggris dan bahasa jawa. Persamaannya yaitu (1) beberapa pola kalimat sederhana memiliki kesamaan yaitu SP dan SPO. (2) element utama dalam kalimat adalah subjek dan predikat. Perbedaannya yaitu (1) dalam bahasa jawa predikat dapat diisi oleh kata kerja, kata benda, kata sifat, numerial dan frase preposisi tetapi dalam bahasa inggris predikat hanya dapat diisi oleh karta kerja saja. (2) dalam bahasa inggris predikat harus dalam bentuk frase kata kerja seperti auxiliary verb, linking verb, atau kata kerja, sedangkan dalam bahasa jawa predikat diisi oleh kata kerja, kata sifat, dan frase preposisi.
\end{abstract}

Kata kunci: analisis kontrastif, kalimat sederhana Bahasa Inggris, kalimat sederhana Bahasa Jawa

\begin{abstract}
This research studied about English and Javanese simple sentences which aimed to find the similarities and differences between English simple sentences and Javanese language. This study is descriptive qualitative research that applied contrastive analysis as the methodology. The data were taken from English textbooks and Javanese magazines. The results of this study showed there were similarities and differences in English and Javanese language simple sentences. The similarities were (1) some of simple sentence have similar patterns were SP for verbal sentence and SPO patterns. (2) the major elements were subject and predicator. The differences were (1) Javanese language had $S P$ pattern for nominal, adjectival, prepositional, and numeral sentence. While in English there was no pattern. (2) In English, predicator must be in verb phrase: auxiliary verbs, linking verbs, or action verbs. However, In Javanese language, the predicator of a sentence might be in verb phrase, adjectival phrase, and prepositional phrase.
\end{abstract}

Keywords: contrastive analysis, English simple sentence, Javanese language simple sentence

\section{Introduction}

Language plays the most important role in life because it is as a basis in communication (Semadi, Suandi and Putrayasa, 2014). Dummnet (2002) states that people need language as means of communication to express their feeling, thought, and desire. It can be said that language is used by human as a tool to communicate with each other. Every language on earth is unique. Two different languages must be difference from each other; however, it is likely that grammatical structures of two languages have similarities in some aspects (Lado in Budasi, 2012).

English is one of universal languages; the language is understood and spoken nearly everywhere on the earth. It constitutes the channel or medium of communication. In other words, English is the communication means using by people over the world known as international language. It can be used as the instruction of expressing and conveying ideas in many aspects of life. In this modern era, English is needed by many people in the world. This is due to the fact that by having a good ability in English, people can carry out many of their 
plans successfully, like continuing study aboard, creating business, and so on. In addition, English helps people to interact and communicate for making mutual understanding. Therefore, English becomes the language learned by people in every country in the world.

In Indonesia, teaching English is known as teaching of a foreign language. It could be said that Bahasa Indonesia is the mother tongue of Indonesian students and English is as the target language which is learned by the students. It means that English is not used as a means of daily communication, but only taught as a school subject and a skill. However, in studying English, some of the students assume that it is not difficult and the rest may feel that studying English is very difficult, for example, in speaking and in writing. They always use their first language in daily communication, so when they must speak English or write something in English, they get some difficulties. Based on that phenomena, it can be concluded that there are many problem faced by the students in study English especially those who speak Javanese language (Kurniawati, 2013). The problems may come from the differences of the aspect of language because no language can exactly same.

Javanese language is a language used in East Java Province, Central Java, and other parts of Indonesia such as in West Java, Sumatra, Bali, and Lombok. It is also used as a tool to communicate in Suriname Republic, New Caledonia, and Johor island (Wedhawati et al., 2006) (Nothofer in Suryadi, 2010). According to Wedhawati et al (2006) Javanese language has 75.5 million native speakers and it is in $11^{\text {th }}$ position of the biggest number of speakers in the world. Javanese language is a natural language that has been described grammatically and practically has rarely compared in written form with English. This language is widely used as a means of communication between people in Java and outside Java in formal and informal settings. As a language of widespread communication, Javanese language needs a vast increase in vocabulary item. This language is a natural language whose vocabulary is limited. It depends largely on Arabic, Sanskrit, Indonesian and other international language like English loan words to complete the most recent technical terms which are not available in Javanese language.

In view of every language has its basic structure of sentences, so certainly there are some differences between the rules of simple sentences in each language that can lead some difficulties faced by students. Therefore comparing both simple sentence patterns of English and Javanese language will be useful for teaching both languages. According to Budasi (2012), the differences and the similarities of grammatical structures of languages are significant and can be used to determine the strategy in teaching languages.

Tarigan (2009) explains that Contrastive analysis is an activity that tries to compare between two language structures, and to identify the differences and similarities between both languages. It is the common term used in applied linguistics to compare two languages, the target language in language teaching and the student's mother tongue (Kartawinata in Budasi 2012). Lado (in Widyasari 2015) states that contrastive analysis is a method for comparing the elements of different languages in terms of form and function to obtain the similarities and differences that can be useful for teaching both language. Most theories of language learning and acquisition mentioned that contrastive analysis is one of the best references a teacher can have to overcome students' language mistakes (Gleason in Budasi, 2012).

English simple sentences are completely different from Javanese language simple sentences. In general a simple sentence in English may be formulated as Noun Phrase (NP) + Verb Phrase (VP) because all English sentences contain a VP (Kartawinata in Budasi 2012). However, in Javanese language simple sentences do not always contain VP. In some cases, a simple sentence in this language may contain VP. So the simple is not NP + VP but it is more common to use the formula NP + Predicate (Pred) because the predicate may be a NP or AP or Adjp. Based on the statement above, the researcher considered that a contrastive analysis between English and Javanese language simple sentences was interesting to be analyzed. The aims of the research were to find the similarities and differences between English simple sentence and Javanese language simple sentence. 


\section{Research Design and Method}

This research was qualitative research. Qualitative research has descriptive characteristic, which means that the gathered of the data are from words, pictures, and not numbers form, if it has numbers, it is just as supporting the data (Danim, 2002). It also allows the researcher to make an interpretation of what the researcher sees, hears, and understands (Craswell, 2009). The aims of descriptive qualitative are to describe any situation, condition, or phenomenon in the society in order to show the characteristics of the phenomenon and to explain why certain people behave in that way (Emzir, 2011). Therefore, the researcher used descriptive qualitative in this study in order to describe the similarities and differences between English and Javanese language simple sentences.

The primary data sources of this research were taken from textbooks and magazine which concerned with the research problems. The primary data were limited from English textbooks and Javanese magazines. The researcher selected English textbooks because they reflected native speakers' English. The researcher chose Jayabaya and Penjebar Semangat magazines because all articles in those magazines were written in Javanese language and reflected native speakers' Javanese. This kind of technique is known as documentary. According to Arikunto (2006), documentary means that the data is collected from note, books, newspaper, magazine, transcript, agenda, and so on.

\section{Finding and Discussion}

In this description of the data, the researcher showed the data taken from English textbooks. From those sources of the data, the researcher found 181 simple sentences. The total number of SP pattern was 27 sentences (14, 91\%), SPA pattern was 25 sentences (13, $81 \%)$, SPC pattern was 31 sentences $(17,13 \%)$, SPO pattern was 34 sentences $(18,78 \%)$, SPOC was 20 sentences $(11,05)$, SVOO pattern was 21 sentences $(11,60 \%)$, and SPOA pattern was 23 sentences (12,71\%). The data of Javanese language simple sentence found in Jayabaya magazine and Penjabar Semangat was 194 Javanese language simple sentences. The total number of SP pattern for verbal sentence was 21 sentences $(10.82 \%)$, SP pattern for nominal pattern was 15 sentences (7.73\%), SP pattern for adjectival sentence was 14 sentences $(7.22 \%)$, SP pattern for numeral sentence was 10 sentences $(5.15 \%)$, SP pattern for prepositional sentence was 22 sentences $(11.34 \%)$, SPO pattern was 33 sentences $(17.01 \%)$, SPC pattern was 27 sentences $(13.92 \%)$, SPCO pattern was 30 sentences (15.46) and SPA pattern was 22 sentences (11.34\%).

The comparison of simple sentence patterns in both languages shows there are some similarities among the pattern in two languages. The similarities can be seen as follows:

\section{SP pattern for verbal sentence}

The SP pattern for verbal sentence in both Javanese and English sentences are similar. Both patterns have noun phrase as the subject and verb phrase as predicator of the sentences, which considered as grammatical sentence in the two languages. Besides, both languages require intransitive verb for constructing this patter. Intransitive verb is a verb that does not need a direct object to complete the meaning. It can be proven by examples below:

\begin{tabular}{|c|c|c|}
\hline No & English Simple Sentences & Javanese Simple Sentences \\
\hline 1 & $\frac{\mathrm{He}}{\mathrm{S}} \frac{\text { smiles }}{\mathrm{P}}$ & $\begin{array}{c}\frac{\text { Dheweke mesem }}{\mathrm{S}} \frac{\mathrm{P}}{\mathrm{P}} \\
\text { 'He smiles' }\end{array}$ \\
\hline 2 & I $\frac{\text { ran away }}{S \quad P}$ & $\begin{array}{l}\frac{\text { Dheweke mlayu }}{\mathrm{S}} \frac{\mathrm{P}}{\mathrm{P}} \\
\text { 'She runs' }\end{array}$ \\
\hline 3 & $\frac{\text { She slept }}{\mathrm{S}} \frac{\mathrm{P}}{\mathrm{P}}$ & $\frac{\text { Rewangku }}{\mathrm{S}} \frac{\text { turu }}{\mathrm{P}}$ \\
\hline
\end{tabular}




\begin{tabular}{cc}
\hline Her nail broke & 'my servant sleeps' \\
$\mathrm{S}$ & $\frac{\text { Yani meneng }}{\mathrm{S}} \frac{\mathrm{m}}{\mathrm{P}}$ \\
'Yani silences'
\end{tabular}

According to the table 1, it found that SP pattern for verbal sentence in English and Javanese language simple sentences is similar. In the examples above, both subjects in English and Javanese simple sentences are the one who do action and they are filled by NP. Predicator in both languages belongs to intransitive verb which does not require an object and they are filled by VP. So, it can be concluded the formula for SP pattern for verbal sentence in both languages are NP + VP. It means the structure for SP pattern for verbal sentence in both languages is similar.

\section{SPO pattern}

The next similarities are found in SPO pattern between English simple sentence and Javanese language simple sentence. In both languages, the predicator $(P)$ of this pattern is always in the form mono-transitive verb which requires the presence of an object (O). The following are some examples of SPO pattern in English simple sentences and Javanese language simple sentences:

\begin{tabular}{|c|c|c|}
\hline No & English Simple Sentences & Javanese Simple Sentences \\
\hline 1 & $\frac{\text { He }}{\mathrm{S}} \frac{\text { loves }}{\mathrm{P}} \frac{\text { Verona }}{\mathrm{O}}$ & $\begin{array}{l}\frac{\text { aku }}{\mathrm{S}} \frac{\text { nemoni }}{\mathrm{P}} \frac{\mathrm{ibu}}{\mathrm{O}} \\
\text { 'I meet my mother' }\end{array}$ \\
\hline 2 & $\frac{\text { I saw }}{\mathrm{S}} \frac{\text { the moon }}{\mathrm{O}}$ & $\begin{array}{l}\frac{\text { Nuni tuku }}{\mathrm{S}} \frac{\mathrm{dhonat}}{\mathrm{P}} \\
\mathrm{O} \\
\text { 'Nuni buys doughnut' }\end{array}$ \\
\hline 3 & $\frac{\text { We }}{\mathrm{S}} \frac{\text { protect }}{\mathrm{P}} \frac{\text { them }}{\mathrm{O}}$ & $\begin{array}{l}\frac{\text { Bapak maos }}{S} \frac{\text { mather }}{P} \\
\frac{\text { koran }}{O} \\
\text { 'My father read newspaper' }\end{array}$ \\
\hline 4 & $\begin{array}{l}\frac{\text { You write }}{\mathrm{S}} \frac{\mathrm{w}}{\mathrm{P}} \\
\frac{\mathrm{the} \text { letter }}{\mathrm{O}}\end{array}$ & $\begin{array}{l}\frac{\text { Yulia mbuka }}{\mathrm{S}} \frac{\mathrm{P}}{\mathrm{P}} \\
\frac{\text { lawang }}{\mathrm{O}} \\
\text { 'Yulia opened the door' }\end{array}$ \\
\hline
\end{tabular}

As seen table 2, the SPO pattern in both English and Javanese language is similar. In the examples above, the subjects of English simple and Javanese language are the one who does action and are filled by NP. Predicators of both languages are in the form of mono transitive verb and tell what the subject does. The predicators in these sentences are filled by VP. The objects both in English and Javanese language simple sentences are thing or person that receive action and are filled by NP. In sum, the formula for SPO pattern in both languages is NP + VP + NP. It means the structure for SPO pattern in both languages is similar.

The comparison of simple sentence patterns in both languages shows there are some differences among the pattern in two languages. The differences can be seen as follows:

\section{SP pattern for nominal sentence}

The first difference is found in the Pattern Subject-Predicator for nominal sentence in Javanese language which is not found in English. In general, a basic pattern in English is SP which is formulated as NP + VP for all English sentences contain a VP. However, SP pattern in Javanese simple sentence does not always contain VP. Sometimes the VP is replaced by a NP. The following are some examples of English simple sentences and Javanese language simple sentences which can be considered for the purpose of this analysis:

Table 3. SP for nominal sentences in English and Javanese Language 


\begin{tabular}{|c|c|c|}
\hline No & English Simple Sentences & Javanese Simple Sentences \\
\hline 1 & $\begin{array}{l}\frac{\text { My name is }}{\mathrm{S}} \frac{\mathrm{S}}{\mathrm{P}} \\
\frac{\text { Lorenzo }}{\mathrm{C}}\end{array}$ & $\begin{array}{l}\frac{\text { Jenengku }}{\mathrm{S}} \\
\frac{\text { Sivana Sari Devi }}{\mathrm{P}} \\
\text { 'my name is Sivana Sari Devi }\end{array}$ \\
\hline 2 & $\begin{array}{l}\frac{\text { Francesca is }}{\mathrm{S}} \frac{\mathrm{i}}{\mathrm{P}} \\
\frac{\text { a nurse }}{\mathrm{C}}\end{array}$ & $\begin{array}{l}\frac{\text { Suparman } \frac{i k u}{D e t}}{S} \\
\frac{\text { kepala sekolah }}{P} \\
\text { 'Suparman is headmaster' }\end{array}$ \\
\hline 3 & $\frac{\mathrm{He}}{\mathrm{S}} \frac{\text { was }}{\mathrm{P}} \frac{\text { farmer }}{\mathrm{C}}$ & $\begin{array}{l}\frac{\text { Titik iku pelayan }}{\mathrm{S}} \frac{\mathrm{ik}}{\mathrm{Det}} \mathrm{P} \\
\text { 'Tutik is waitress' }\end{array}$ \\
\hline 4 & $\frac{\mathrm{He}}{\mathrm{S}} \frac{\text { is }}{\mathrm{P}} \frac{\text { Italian }}{\mathrm{C}}$ & $\begin{array}{l}\frac{\text { Aryani Puspita kuwi }}{\mathrm{S}} \frac{\text { Det }}{\text { Det }} \\
\frac{\text { ibumu }}{\mathrm{P}} \\
\text { 'Aryani Puspita is }\end{array}$ \\
\hline
\end{tabular}

From the analysis in table 3, it reveals that SP pattern for nominal sentence in English and Javanese simple sentence is totally different. As can be seen in the data table 3, English simple sentences always contain predicator in the form of copular verbs (is, are and were). However in Javanese simple sentences, there are no copular/ to be. In other words, in English there is no sentence like 'Tutik waitress' for it is considered as ungrammatical sentence. In this case, sentence 'Tutik waitress' should be added by copular verb 'is' in order to make as grammatical sentence. Therefore the sentence will be 'Tutik is a waitress'. However, in Javanese simple sentence 'Tutik iku Pelayan' is acceptable as grammatical sentence for Javanese language has no copular verbs.

\section{SP pattern adjectival sentence}

The second difference is found in the Pattern Subject-Predicator for adjectival sentence in Javanese language which is not found in English. In general, a basic pattern in English is SP which is formulated as NP + VP for all English sentences contain a VP. However, SP pattern in Javanese simple sentence does not always contain VP. Sometimes the VP is replaced by an Adjective. The following are some examples of English simple sentences and Javanese simple sentences which can be considered for the purpose of this analysis:

Table 4. SP for adjectival sentences in English and Javanese Language

\begin{tabular}{|c|c|c|}
\hline No & English Simple Sentences & Javanese Simple Sentences \\
\hline 1 & $\begin{array}{l}\frac{\text { They }}{S} \frac{\text { were }}{P} \\
\text { happy } \\
C\end{array}$ & $\begin{array}{l}\frac{\text { Kowe }}{\mathrm{S}} \frac{\mathrm{iku}}{\text { Det } \mathrm{ayu}} \\
\text { 'You are beautiful' }\end{array}$ \\
\hline 2 & $\begin{array}{l}\frac{\text { Peggy seems }}{\mathrm{S}} \frac{\mathrm{s}}{\mathrm{P}} \\
\frac{\text { angry }}{\mathrm{C}}\end{array}$ & $\begin{array}{l}\frac{\text { Klambine }}{\mathrm{S}} \frac{\text { abang }}{\mathrm{P}} \\
\text { 'his shirt is red' }\end{array}$ \\
\hline 3 & $\begin{array}{l}\frac{\text { It sounds }}{\mathrm{S}} \frac{\mathrm{sou}}{\mathrm{P}} \\
\frac{\text { terrible }}{\mathrm{C}}\end{array}$ & $\begin{array}{l}\frac{\text { Wonge }}{S} \frac{\text { dhuwur }}{P} \\
\text { 'he is tall' }\end{array}$ \\
\hline 4 & $\begin{array}{l}\frac{\text { They were }}{\mathrm{S}} \frac{\mathrm{P}}{\mathrm{P}} \\
\frac{\text { poor }}{\mathrm{C}}\end{array}$ & $\begin{array}{l}\frac{\text { Priyayine }}{S} \\
\frac{\text { nggantheng }}{P} \\
\text { 'he is handsome' }\end{array}$ \\
\hline
\end{tabular}

From the analysis table 4, SP pattern for adjectival in English and Javanese simple sentence is totally different. As can be seen in the data table 4, English simple sentences always contain predicator in the form of copular verb or linking verb. However in Javanese simple 
sentences, there are no copular/ to be. In other words, in English there is no sentence like 'he tall' for it is considered as ungrammatical sentence. In this case, sentence 'he tall' should be added by copular verb 'is' in order to make it as grammatical sentence. Therefore the sentence will be 'he is tall'. However, in Javanese simple sentence 'Wonge dhuwur' is acceptable as grammatical sentence for Javanese does not have copular verbs.

\section{SP (PP) pattern}

The third difference is found in the Pattern Subject-Predicator for prepositional sentence in Javanese language which is not found in English. In general, a basic pattern in English is SP which is formulated as NP + VP for all English sentences contain a VP. However, SP pattern in Javanese language simple sentence does not always contain VP. Sometimes the VP is replaced by PP. The following are some examples of English simple sentences and Javanese language simple sentences which can be considered for the purpose of this analysis:

\begin{tabular}{|c|c|c|}
\hline No & English Simple Sentences & Javanese Simple Sentences \\
\hline 1 & $\begin{array}{l}\frac{\text { I am }}{\mathrm{S}} \frac{\text { in Times }}{\mathrm{P}} \\
\mathrm{S} \text { gqure }\end{array}$ & $\begin{array}{l}\frac{\text { Yulia neng kamare }}{\mathrm{S}} \frac{\mathrm{P}}{\mathrm{P}} \\
\text { 'Yulia is in her room' }\end{array}$ \\
\hline 2 & $\frac{\mathrm{I}}{\mathrm{S}} \frac{\mathrm{am}}{\mathrm{P}} \frac{\text { in Verona }}{\mathrm{A}}$ & $\begin{array}{l}\frac{\text { Aku menyang }}{\mathrm{S}} \frac{\mathrm{P}}{\mathrm{J}} \\
\frac{\text { Jakarta }}{\text { I go to Jakarta }}\end{array}$ \\
\hline 3 & $\begin{array}{l}\frac{\mathrm{He}}{\mathrm{S}} \frac{\text { is }}{\mathrm{P}} \frac{\text { at a }}{\mathrm{A}} \\
\text { Wine Auction }\end{array}$ & $\begin{array}{l}\frac{\text { lbu ing pawon }}{\mathrm{S}} \frac{\mathrm{P} \text { ) }}{\text { 'mother is in kitchen }} \\
\text { 'mothe }\end{array}$ \\
\hline 4 & $\frac{1}{S} \frac{\text { was }}{\mathrm{P}} \frac{\text { at home }}{\mathrm{A}}$ & $\begin{array}{l}\frac{\text { Adriyani saka toko }}{\mathrm{S}} \frac{\mathrm{P}}{\text { 'Aryani is from grocery' }} \\
\text { 'As fro }\end{array}$ \\
\hline
\end{tabular}

From the analysis table 5, SP pattern for prepositional sentence in English and Javanese simple sentence is totally different. As can be seen in the data above, English simple sentences always contain predicator in the form of copular verb or linking verb. However in Javanese simple sentences, there are no copular/ to be. In other words, in English there is no sentence like 'Mother in kitchen' for it is considered as ungrammatical sentence. In this case, sentence 'mother in kitchen' should be added by copular verb 'is' in order to make it as grammatical sentence. Therefore the sentence will be 'mother is in kitchen'. However, in Javanese simple sentence 'lbu ing pawon' is acceptable as grammatical sentence for Javanese language does not have copular verbs.

\section{SP pattern for numeral sentence}

The fourth differences are found in the Pattern Subject-Predicator for numeral sentence in Javanese language which is not found in English. In general, a basic pattern in English is SP which is formulated as NP + VP for all English sentences contain a VP. However, SP pattern in Javanese language simple sentence does not always contain VP. Sometimes the VP is replaced by Numeral. The following are some examples of English simple sentences and Javanese simple sentences which can be considered for the purpose of this analysis:

Table 6. SP for numeral sentences in English and Javanese Language

\begin{tabular}{lll}
\hline No & English Simple Sentences & Javanese Simple Sentences \\
\hline 1 & $\frac{\text { Roberto }}{\mathrm{S}} \frac{\text { s }}{\mathrm{P}}$ & $\frac{\text { Anake }}{\mathrm{S}} \frac{\mathrm{telu}}{\mathrm{P}}$ \\
& $\frac{\text { twenty one years old }}{\mathrm{C}}$ & 'he has 3 children' \\
2 & $\underline{\text { She has }}$ & Bocah cilik \\
\hline
\end{tabular}




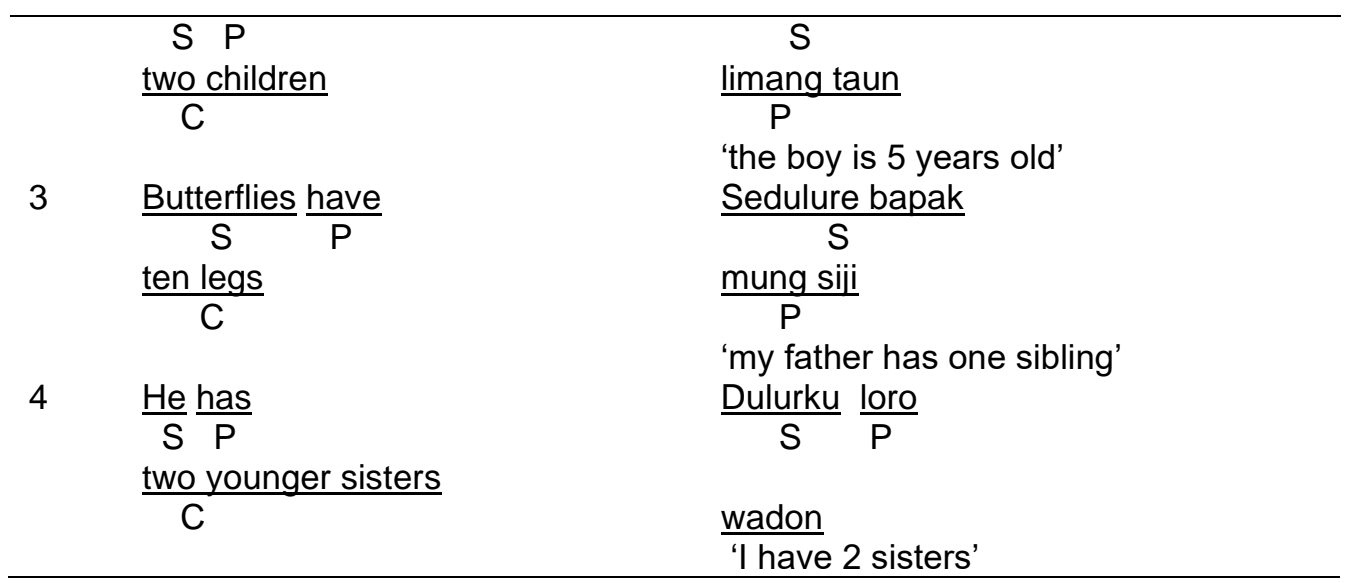

The analysis of table 6 shows SP pattern for numeral sentence in English and Javanese simple sentence is totally different. As can be seen in the data table 6, English simple sentences always contain predicator in the form of copular verb or transitive verb 'have'. However in Javanese simple sentences, there are no copular/ to be. In other words, in English there is no sentence like 'She two children' for it is considered as ungrammatical sentence. In this case, sentence 'She two children' should be added by transitive verb 'has' in order to make it as grammatical sentence. Therefore the sentence will be 'She has two children'. However, in Javanese simple sentence 'Anake loro' is acceptable as grammatical sentence.

\section{SPC pattern}

The last difference is found in SPC English simple sentence pattern. The verbs in these patterns are intensive verb and followed by $\mathrm{Cs}$ - subject complement. Intensive verb is known as copular verbs or linking verbs such as be, seem, appear, look and become. In contrast, there is no such pattern similar in Javanese simple sentences, since Javanese language does not have copular verbs. The following are some examples of English simple sentences and Javanese simple sentences which can be consider for the purpose of this analysis:

Table 7. SVC sentences in English and Javanese Language

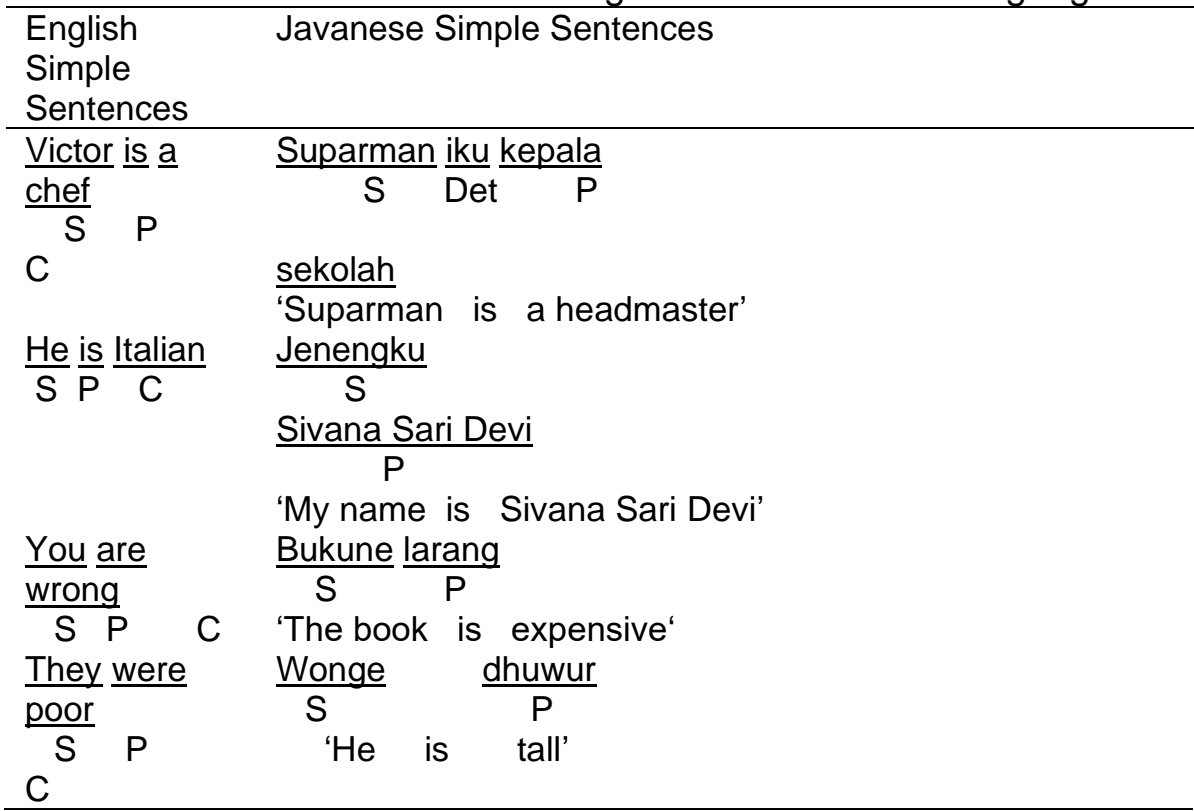

From the analysis table 7, it reveals that SPC pattern in English and Javanese simple sentence is totally different. As can be seen in the data table 7, English simple sentences always contain predicator in the form of copular verb (is, are and were). However in Javanese simple sentences, there are no copular/ to be. In other words, the English pattern of SPC can be used for Javanese adjectival sentence (SP) and nominal sentence (SP). 


\section{Conclusion and Suggestion}

The results of this study showed there were similarities and differences in English and Javanese language simple sentences. The similarities of English and Javanese language simple sentences were (1) some of simple sentence patterns were similar in both languages that were SP for verbal sentence and SPO patterns. (2) The major elements of simple sentences in the two languages were subject and predicator. The differences of English and Javanese language simple sentences were (1) Javanese language had SP pattern for the nominal sentence, adjectival sentence, prepositional sentence, and numeral sentence. While in English there was no pattern like that. (2) In English, the predicator of a sentence must be in verb phrase: auxiliary verbs, linking verbs, or action verbs. However, In Javanese language, the predicate of a sentence might be in verb phrase, adjectival phrase, noun phrase, numeral phrase and prepositional phrase.

According to the conclusion above, the researcher realizes that this study still needs more extension. Since this study only discussed one type of clauses that is simple sentence. As we know that actually there are still three types of clauses namely compound sentence, complex sentence, and compound - complex sentence. Thus, the researcher suggests another researcher to analyze them

\section{References}

Arifin, (1987). Tipe Kalimat Bahasa Jawa. Jakarta: Departement Pendidikan dan Kebudayaan

Arikunto, S. (2006). Metodologi Penelitian. Jakarta: PT. RinekaCipta.

Budasi, I.G. (2012). Comparison of Verb Phrases in English and Anakalang Language Basic Sentences. PRASI, 7(14), 23 - 29

Budasi, I.G. (2012). Constructive Analysis of Verb Phrases in English and Balinese Language Basic Sentences. PRASI, 8(13), 21 - 27

Danim, S. (2002). Menjadi Peneliti Kualitatif: Ancangan Metodologi, Presentasi, dan Publikasi Hasil Penelitian untuk Mahasiswa dan Penelit Pemula Bidang IImu-ilmu Sosial, Pendidikan, dan Humaniora. $1^{\text {st }}$ Ed. Pustaka Setia. Bandung.

Dummet, M. (2002). Language as our Means of Communication. Boulder: Universitas of Colorado

Emzir. (2011). Metedologi Penelitian Kualitatif Analisis Data. Jakarta: Rajawali Press

Kurniawati, W. (2013). A Constructive Analysis of Imperative Sentences between English and Javanese Language. Published Thesis. Institute of Islamic Studies

Quirk, R \& Greenbaum, S. (1973). A University Grammar of English. Hongkong: Commonwealth Printing Press Ltd

Robert, P. (1967). The Roberts English Series: A Linguistic Program. Sacramento: California State Department of Education

Semadi, Y.P., Suandi, I.N., \&Putrayasa, I.B. (2014). Perbandingan Frase Verba dalam Bahasa Indonesia dengan Frase Verba Bahasa Belanda: Sebuah Kajian Analisis Konstratif. e-Journal Program Pascasarjana Universitas Pendidikan Ganesha, 3

Sudaryanto. (1991). Tata Bahasa Baku Bahasa Jawa. Yogyakarta: Duta Wacana University Press

Tarigan, G.(2009). Pengajaran Analisis Kontrastif Bahasa. Bandung: Angkasa.

Wedhawati et al. (2006). Tata Bahasa Jawa Mutakhir (Edisi Revisi). Jakarta: Pusat Bahasa Departemen Pendidikan Nasional.

Widyasari, F.E. (2015). A Constructive Analysis of English and Javanese Compound Word Constructions. Published Thesis. Universitas Negeri Semarang 